\title{
Invertebrate communities in permanent and temporary high mountain lakes (Tatra Mts)
}

\author{
A. Kownacki ${ }^{1}$ \\ J. Galas ${ }^{1}$ \\ E. Dumnicka ${ }^{1}$ \\ S. Mielewczyk ${ }^{2}$
}

Keywords : high mountain lake, benthic fauna, water chemistry, acidification, hydroperiod.

Water chemistry and macroinvertebrates of four high mountain lakes (alt. 1657-1784 m) were investigated. The lakes are ultraoligotrophic with naturally slightly acidic water. In three lakes these water level changed substantially during the year while in one it remained constant. Moreover, trophic status was higher in one than in the other three. Oligochaeta and Chironomidae dominated the invertebrate fauna of all lakes. Benthic faunal composition depended mainly on ecological factors such as substrate, trophic status, and hydroperiod. It appears that anthropogenic acidification has so far not affected faunal composition.

\section{Les communautés d'invertébrés dans des lacs permanents et temporaires de haute montagne (Hauts Tatras)}

Mots clés : lac de haute montagne, faune benthique, chimie de l'eau, acidification, assèchement.

Les paramètres chimiques de l'eau et la faune benthique de quatre lacs des Hauts Tatras (1657-1784 m) ont été étudiés. Les lacs sont ultraoligotrophes avec des eaux naturellement un peu acides. Dans trois lacs les changements de niveau de l'eau sont variables, dans un autre le niveau reste constant. De plus, l'état trophique d'un lac est plus élevé. Les espèces d'oligochètes et de Chironomidae sont les plus nombreuses parmi les invertébrés recensés dans tous les lacs étudiés. La composition de la faunebenthique dépend principalement des facteurs écologiques comme : qualité du substrat, trophie de l'eau et durée des périodes d'assèchement. Il apparaît que l'acidification causée par l'activité humaine n'affecte pas le peuplement benthique jusquà présent.

\section{Introduction}

The benthic fauna of the Tatra Mountains lakes has been studied since the beginning of the 20th century (Minkiewicz 1914). Nevertheless knowledge about it is still incomplete. In the four studied lakes situated in the Gasienicowa Valley only 17 taxa of invertebrate fauna were previously recorded (Minkiewicz 1914, Hrabe 1942). At the time of increasing water eutrophi-

1. Institute of Freshwater Biology, Polish Academy of Sciences, Slawkowska 17, 31-016 Kraków, Poland.

2. Research Centre for Agricultural and Forest Environment, Polish Academy of Sciences, Bukowska 19, 60-809 Poznan, Poland. cation and high sulphur and nitrogen emission, which leads in regions with substratum of low buffering capacity to acidification of water bodies, better knowledge of biocenoses composition and structure including benthic community is very important. The study of the Slovak Tatra Mountains lakes showed that their fauna are threatened by anthropogenic acidification (Vranovskÿ et al. 1994).

Recently, many studies were devoted exclusively to water chemistry changes in lakes situated in Tatra Mountains (Kopácek \& Stuchlík 1994, Wojtan \& Galas 1994, Bombówna \& Wojtan 1996, Galas et al. 1996, Rzychoń \& Worsztynowicz 1995). However, all these studies did not answer the basic question : what determines the structure and composition of the Tatra lakes biocenoses? 
In many high mountain water bodies periodical drying out is a meaningful ecological factor. This problem was studied in a Tatra stream (Kownacki 1985). However, the effect of gradual water level decrease (until periodical drying of the lake bottom) on the composition of benthic communities is still not known. The aim of hydrochemical and hydrobiological investigations on four selected Tatra lakes presented here, which started in 1993 and continued until 1998, was to answer this question. In this paper, connections occurring between benthic invertebrates' composition and water chemistry results are described ; the composition and structure of benthic communities in drying and permanent lakes are also compared.

\section{Study area and methods}

The investigations were carried out in four high mountain lakes (Table 1) situated above the timberline in the area of the Tatra National Park. The studied lakes are situated very close to each other, in the same valley. Two of them : Zielony Staw and Dtugi Staw lakes are filled with water the whole year, while the lakes are frozen from October/November until May/June. Although in Dtugi Staw lake water level decreases significantly in winter, even to $5 \mathrm{~m}$, it never dries up to the bottom. In Dwoisty Staw lakes during winter water disappears through the underground outflow (Litynski 1917, Kownacki, unpubl.) and in spring all these lakes fill up again with water from the melting snow. The glacial relict, Branchinecta paludosa O.F. Müller (Crustacea) inhabited that lake till sixties (Dyduch-Falniowska \& Smagowicz 1980).

In each studied lake the type of the bottom is different. The middle part of Dtugi Staw lake bottom is covered by moss Warnstorfia exannulata (Schimp) Loeske ( $1 \mathrm{~m}$ height), which presence was detected at the be- ginning of this century (Olszewski 1948). There are also big boulders, stones and some mud. Zielony Staw lake bottom is covered by mud, while bottom of both Dwoisty Wschodni and Zachodni lakes is covered entirely by big boulders, with small aggregations of mud. The artificially introduced fish Salvelinus fontinalis (Mitch.) is only present in Zielony Staw lake. They significantly changed the zooplankton composition (Gliwicz 1985) and probably also influenced the benthic invertebrate communities.

Quantitative samples of benthic invertebrate were taken using corer for mud (Dtugi Staw and Zielony Staw lakes) while from the stony littoral only qualitative samples were taken using the kick method (Frost et al. 1971). Each time, 4 profundal and 4 littoral samples were taken. In Dwoisty Zachodni and Wschodni lakes only qualitative benthic samples were taken by a SCUBA diver from the boulders area and mud. The collected samples were washed in a net with a mesh size of $0.25 \mathrm{~mm}$; macroinvertebrates were removed under stereoscopic microscope and preserved in $4 \%$ formaldehyde.

Water samples for chemical analyses were taken from the lakes with varying frequency (Table 2) and analysed according to Standard Methods (1992).

\section{Results}

\subsection{Hydrochemistry}

The waters of the studied lakes were very weakly mineralised with low calcium (average $2.5 \mathrm{mg} \mathrm{Ca}$ $\mathrm{dm}^{-3}$ ) and magnesium concentration (average $: 0.2 \mathrm{mg}$ $\mathrm{dm}^{-3}$ for Zielony and Dtugi Staw lakes ; $0.6 \mathrm{mg} \mathrm{dm}^{-3}$ for Dwoisty Staw lakes). Alkalinity and conductivity were also very low (Table 2), and increased a little only during the snow melting period ( $43 \mu \mathrm{S}$ in Dtugi, 35

Table 1. Basic parameters of the lakes studied.

Tableau 1. Les paramètres physiques fondarnentaux des lacs étudiés.

\begin{tabular}{lccccccc}
\hline Lake & $\begin{array}{c}\text { Altitude } \\
\mathrm{m}\end{array}$ & $\begin{array}{c}\text { Area } \\
\text { ha }\end{array}$ & $\begin{array}{c}\text { Depth } \\
\text { max. } \mathrm{m}\end{array}$ & $\begin{array}{c}\text { Volume } \\
10^{3} \mathrm{~m}^{3}\end{array}$ & $\begin{array}{c}\text { Bottom } \\
\text { character }\end{array}$ & $\begin{array}{c}\text { Lake } \\
\text { character }\end{array}$ & Remarks \\
\hline Zielony & 1672 & 3,844 & 15,1 & 260.50 & slime & permanent & Salmonids \\
Dtugi & 1784 & 1,593 & 10,6 & 81,06 & $\begin{array}{c}\text { stones, slime, } \\
\text { moss } \\
\text { permanent, } \\
\text { water level } \\
\text { fluctuating }\end{array}$ & fishless \\
$\begin{array}{l}\text { Dwoisty } \\
\text { Wschodni }\end{array}$ & 1657 & 1,418 & 9,2 & 48,10 & boulders & intermittent & fishless \\
$\begin{array}{l}\text { Dwoisty } \\
\text { Zachodni }\end{array}$ & 1657 & 0,905 & 7,9 & 23,20 & boulders & periodical & fishless \\
\hline
\end{tabular}


Table 2. Hydrochemical characteristics (range) of the lake studied and sampling periods.

Tableau 2. Caractéristiques chimiques de l'eau des lacs étudiés (valeurs extrêmes des paramètres choisis) et périodes d'échantillonnage.

\begin{tabular}{|c|c|c|c|c|c|c|c|c|c|}
\hline & \multicolumn{2}{|c|}{ Zielony Staw } & \multicolumn{5}{|c|}{ Dtugi Staw } & \multirow{2}{*}{$\begin{array}{c}\begin{array}{c}\text { Dwoisty } \\
\text { Wschodni }\end{array} \\
1995 / 96\end{array}$} & \multirow{2}{*}{$\begin{array}{c}\begin{array}{c}\text { Dwoisty } \\
\text { Zachodn }\end{array} \\
1995 / 96\end{array}$} \\
\hline & 1993 & 1994 & 1993 & 1994 & 1996 & 1997 & 1998 & & \\
\hline No. of water samples & 23 & 23 & 22 & 25 & 7 & 10 & 3 & . 6 & 6 \\
\hline Months of fauna & $\mathrm{X}$ & $\mathrm{X}$ & $\mathrm{X}$ & $\mathrm{x}$ & VII, $\dot{X}$ & VII,VIII,IX & VI,VII & VI,VII,IX & VI,VII,IX \\
\hline Sampling & & & & & & $X$ & & V,VIII,IX & V,VIII,IX \\
\hline $\mathrm{pH}$ & $5,9-7,1$ & $6,2-6,8$ & $5,1-6,4$ & $5,2-6,6$ & $4,3-5,8$ & $5,1-5,9$ & $5,1-5,9$ & $4,3-6,2$ & $4,2-6,5$ \\
\hline Conductivity $\mu \mathrm{S} \mathrm{cm}^{-1}$ & $19,7-27,4$ & $18,7-26,3$ & $15,9-24,6$ & $14,1-24,9$ & $15,4-43,1$ & $18,0-31,3$ & $13,9-43,8$ & $10,2-37,4$ & $9,4-45,5$ \\
\hline Alkalinity mval dm $\mathrm{dm}^{-3}$ & $0,001-0,01$ & $0,002-0,09$ & $0-0,06$ & $0-0,09$ & $0-0,04$ & $0,02-0,05$ & $0,03-0,05$ & $0,06-0,22$ & $0,08-0,22$ \\
\hline $\mathrm{Ca}^{2+} \mathrm{mg} \mathrm{dm}^{-3}$ & & $2,5-3,5$ & $1,5-3,1$ & $1,4-3,4$ & $1,0-2,1$ & $1,1-2,2$ & $1,4-2,0$ & $1,6-2,3$ & $1,7-2,7$ \\
\hline $\mathrm{Mg}^{+} \mathrm{mg} \mathrm{dm}{ }^{-3}$ & $0,1-0,3$ & $0,1-0,2$ & $0,1-0,2$ & $0,1-0,2$ & $0,1-0,1$ & $0,1-0,2$ & $0,1-0,1$ & $0,4-1,3$ & $0,4-1,1$ \\
\hline $\mathrm{SO}_{4}^{2-} \mathrm{mg} \mathrm{dm}^{-3}$ & $3,0-4,6$ & $3,1-4,1$ & $2,9-4,4$ & $2,7-4,6$ & $2,2-8,8$ & $2,2-3,7$ & $0,7-1,0$ & $1,2-3,2$ & $0,7-2,7$ \\
\hline $\mathrm{N}-\mathrm{NH}_{4}{ }^{+} \mathrm{mg} \mathrm{dm}^{-3}$ & $0,01-0,14$ & $0,05-0,1$ & $0,01-0,03$ & $0,01-0,04$ & $0,01-0,21$ & $0,01-0,14$ & $0,01-0,14$ & $0,21-0,32$ & $0,23-0,34$ \\
\hline $\mathrm{N}-\mathrm{NO}_{3}^{-} \mathrm{mg} \mathrm{dm}^{-3}$ & $0,35-0,90$ & $0,29-0,83$ & $0,58-0,98$ & $0,53-0,92$ & $0,45-0,88$ & $0,49-0,76$ & $0,28-0,7$ & $0,31-0,54$ & $0,06-0,47$ \\
\hline
\end{tabular}

$\mu \mathrm{S}$ in Dwoisty Wschodni lake and $45 \mu \mathrm{S}$ in Dwoisty Zachodni lake). Waters of these lakes (except for Zielony Staw) were slightly acidic and the lowest values of $\mathrm{pH}$ were noted just after the end of snow melting period ( $\mathrm{pH} 4.2$ - 4.5), later the $\mathrm{pH}$ slowly increased, so in summer time the maximal value of water $\mathrm{pH}$ was 6.2 - 6.5. In earlier studies from 1960-1963 (Oleksynowa \& Komornicki 1989) carried out on the same lakes, similar summer values of $\mathrm{pH}$ were found. Studied lakes had ultraoligotrophic waters with very low organic matter contents expressed as $\mathrm{BOD}_{5}$, which ranged from 0.6 to $3 \mathrm{mg} \mathrm{O}_{2} \mathrm{dm}^{-3}$. Concentration of ammonium in water was very low (Table 2), especially in Zielony and Dtugi Staw lakes. A small amount ( $<1 \mathrm{mg}$ $\left.\mathrm{dm}^{-3}\right)$ of nitrogen as nitrate $\left(\mathrm{N}-\mathrm{NO}_{3}\right)$ was present.

\subsection{Benthic invertebrate communities}

In all the studied lakes, Nematoda were very abundant. In spite of the sampling method which was not adequate for catching these meiobenthic invertebrates, they usually formed more than $40 \%$ of the benthic fauna in Dtugi and Dwoiste lakes and about $20 \%$ in Zielony lake. In macrobenthos community Oligochaeta and Chironomidae dominated. The total percentage share of all remaining groups was no more than $11 \%$ (Table 3). The high number of Chironomidae was ob- served in almost all the studied lakes and habitats, while they were less abundant in Dtugi Staw lake and in the muddy deep part of Zielony Staw lake. Percentage share of oligochaetes varied from lake to lake. They were very abundant near the shore $(92 \%)$ and in the deep part $(42 \%)$ of Dtugi Staw lake as well as in the deep part of Zielony Staw lake (85\%). In Dwoiste Stawy lakes they were less abundant, especially in Dwoisty Wschodni lake and the species composition was very poor.

The dominant species, in the profundal zone of Dtugi Staw lake, were Micropsectra radialis, Heterotrissocladius marcidus (Chironomidae), and Cernosvitoviella tatrensis (Oligochaeta, Enchytraeidae). In the littoral zone, the Enchytraeidae, mainly from the amphibiotic genus Cognettia characteristic for acidified waters and soils, dominated. In both Dwoisty Staw lakes, Chironomidae dominated : in Wschodni lake Zavrelimyia sp., Cricotopus (C.) gr. fuscus and Corynoneura sp. in smaller number. In Zachodni lake the first dominant was larvae of Corynoneura sp., the second were the two Tanypodinae Zavrelimyia sp. and Macropelopia sp. The important element of fauna in both Dwoiste lakes was Oligochaeta from the genus Cernosvitoviella, mainly C. tatrensis. Very small number of individuals from Cognettia genus was found. In 
Table 3. Percentage composition of benthic macroinvertebrate groups in some Tatra lakes

Tableau 3. Importance relative (en \%) des groupes de macroinvertébrés benthiques dans quelques lacs des Tatras.

\begin{tabular}{lcccccccc}
\hline \multicolumn{1}{c}{ Lakes } & \multicolumn{2}{c}{ Zielony } & \multicolumn{2}{c}{ Dtugi } & \multicolumn{2}{c}{$\begin{array}{c}\text { Dwoisty } \\
\text { Wschodni }\end{array}$} & \multicolumn{2}{c}{$\begin{array}{c}\text { Dwoisty } \\
\text { Zachodni }\end{array}$} \\
& $15 \mathrm{~m}$ & $0.5 \mathrm{~m}$ & $10 \mathrm{~m}$ & $0.5-1 \mathrm{~m}$ & $8-9 \mathrm{~m}$ & $0.5-1 \mathrm{~m}$ & $6-7 \mathrm{~m}$ & $0.5-1 \mathrm{~m}$ \\
Taxa & & & & & & & & \\
\hline Turbellaria & - & 0,36 & - & - & 7,81 & 0,28 & - & - \\
Oligochaeta & 83,19 & 11,60 & 42,08 & 92,21 & 0,94 & 11,31 & 16,10 & 29,20 \\
Bivalvia-Sphaeridae & 2,17 & & & & & & & \\
Plecoptera & - & 4,81 & - & - & - & - & 0,61 & - \\
Trichoptera & - & - & - & 0,29 & 3,75 & 1,93 & 2,43 & 6,19 \\
Diptera & & & & & & & & \\
C h i r o n o m i d a e & 14,64 & 83,06 & 57,24 & 6,24 & 84,69 & 83,44 & 77,52 & 59,31 \\
L i m o n i i d a e & - & - & 0,68 & - & - & - & - & - \\
Coleoptera & - & 0,17 & - & 1,26 & 2,81 & 3,04 & 3,34 & 5,30 \\
\hline
\end{tabular}

the profundal zone of Zielony Staw lake the composition of oligochaete fauna was different from that in other lakes. Enchytraeidae were found in small number, Nais variabilis (Naididae) and young specimens of Tubificidae dominated. All mature specimens were classified as Tubifex montanus. In the littoral stony zone there were more Chironomidae : Heterotrissocladius marcidus and Corynoneura sp. Only in this lake few Plecoptera and Bivalvia taxa (genus Pisidium) were found. Coleoptera were very rare, while in the remaining lakes they constituted low, but stable percent of total benthic fauna. In total, in all the studied lakes only 6 species from the Dytiscidae family were identified. Almost entirely they belonged to a group of high ecological specialisation - adapted to life in cold, oligotrophic waters. Larvae of Trichoptera were not found in Zielony Staw lake, while in Dwoisty Staw lake they were present in both shallow and deep parts of the bottom and in Dtugi Staw lake only in the littoral zone.

In the studied lakes, 51 taxa were found in total, the highest number was in Dtugi Staw lake (29) and Zielony Staw (28), the lower one in Dwoisty.Wschodni (23) and Zachodni (21) lakes.

\section{Discussion}

The differences in the specific composition of invertebrates communities in the four investigated lakes might result from various reasons. The higher fauna biodiversity found in Zielony Staw lake most probably resulted from its a little higher trophic status and in Dtugi Staw lake from a longer time of study - 4 years -, while Dwoisty Staw lakes - as oligotrophic as the previous one - where the smallest number of species was found were investigated for only 2 years.

In all the studied lakes, in spite of some differences, the composition of Chironomidae fauna was similar and characteristic for oligotrophic High Tatra mountain lakes. Domination of this group and similar composition of species was stated already in 30 -ties ( $\mathrm{Za}-$ vrel 1935, Hrabe 1942, Thienemann 1954). In Alpine and Central Pyrenees lakes, situated on altitudes comparable to the investigated Tatra lakes, the diversity of Chironomidae was higher (Reiss 1968, Laville 1971a \& b, Laville \& Giani 1974) although species known from Tatra lakes were also present there. In compared lakes of the three mountain ranges the domination of Chironomidae was similar : Heterotrissocladius marcidus, Corynoneura, Paratanytarsus austriacus dominated (Laville 1971, Laville \& Giani 1974). Cernosvitoviella tatrensis was very common in Tatra's lakes since the beginning of the century (Kowalewski 1917, Hrabe 1942) until now. The remaining taxa of benthic communities were more changeable and seemed depending on different ecological parameters.

Only in Dtugi Staw lake, in the periodically drying littoral zone, the fauna community with amphibious 
Table 4. Taxa found in the lakes studied.

Tableau 4. Taxons récoltés dans les lacs étudiés.

\begin{tabular}{|c|c|c|c|c|}
\hline Taxa & Zielony & Dtugi & $\begin{array}{l}\text { Dwoisty } \\
\text { Wschodni }\end{array}$ & $\begin{array}{l}\text { Dwoisty } \\
\text { Zachodni }\end{array}$ \\
\hline \multicolumn{5}{|l|}{ TURBELLARIA } \\
\hline Crenobia alpina (Dana) & $\mathrm{X}$ & & & \\
\hline Turbellaria non det. & & & $\mathrm{X}$ & $\mathrm{X}$ \\
\hline NEMATODA non det. & $\mathrm{X}$ & $\mathrm{X}$ & $\mathrm{X}$ & $\mathrm{X}$ \\
\hline APHANONEURA & & & & \\
\hline Aeolosoma sp. Ehren & & $\mathrm{X}$ & & \\
\hline OLIGOCHAETA & & & & \\
\hline Dero dorsalis Fer. & $\mathrm{X}$ & & & \\
\hline Nais pseudobtusa Pig. & & $\mathrm{X}$ & & \\
\hline Nais variabilis Pig. & $\mathrm{X}$ & & & \\
\hline Nais alpina Sperb. & & & & $\mathrm{X}$ \\
\hline Tubifex montanus Kow. & $\mathrm{X}$ & & & \\
\hline Tubificidae gen. spp. (juv.) & $\mathbf{X}$ & & & \\
\hline Mesenchytraeus armatus (Lev.) & $\mathrm{X}$ & & & \\
\hline - sp. Eis. & $\mathbf{X}$ & & & \\
\hline Cernosvitoviella atrata (Bret.) & & $\mathbf{X}$ & & \\
\hline- tatrensis (Kow.) & & $\mathbf{X}$ & $\mathrm{X}$ & $\mathrm{X}$ \\
\hline - carpatica Niel. \&Christ. & & $\mathrm{X}$ & $\mathrm{X}$ & $\mathrm{X}$ \\
\hline - sp. Niel. \&Christ. & $\mathrm{X}$ & $\mathrm{X}$ & $\mathrm{X}$ & $\mathrm{X}$ \\
\hline Cognettia sphagnetorum (Vejd.) & $\mathrm{X}$ & $\mathrm{X}$ & & \\
\hline - glandulosa (Mich.) & & $\mathrm{X}$ & & \\
\hline - cognetti (Issel) & & $\mathrm{X}$ & & \\
\hline - anomala (Cer.) & & $\mathrm{X}$ & & \\
\hline - lapponica Nurm & & $\mathrm{X}$ & & \\
\hline - sp. Niel. \& Christ. & & $\mathrm{X}$ & $\mathrm{X}$ & \\
\hline Marionina argentea (Mich.) & & $\mathrm{X}$ & & \\
\hline Enchytraeus buchholzi Vejd. & & $\mathrm{X}$ & & \\
\hline Achaeta sp. Vejd. & & $\mathrm{x}$ & & \\
\hline Enchytraeidae gen. spp. juv. & & $\mathrm{X}$ & $\mathrm{X}$ & $\mathrm{X}$ \\
\hline Stylodrilus parvus (Hr. \& Cern.) & & $\mathrm{X}$ & & \\
\hline - sp. juv. & $\mathrm{X}$ & $\mathrm{X}$ & & \\
\hline Eiseniella tetraedra (Sav.) & & $\mathrm{X}$ & & \\
\hline BIVALVIA & & & & \\
\hline Pisidium sp. & $\mathbf{X}$ & & & \\
\hline PLECOPTERA & & & & \\
\hline Nemuridae (Nemurella picteti Klp.) & $\mathrm{X}$ & & & \\
\hline Nemuridae juv. & $\mathrm{X}$ & $\mathrm{X}$ & & \\
\hline Diura bicaudata (L.) & $\mathbf{X}$ & & & \\
\hline Perlodidae & $\mathrm{X}$ & & & \\
\hline Plecoptera (juv.) & $\mathrm{X}$ & & & $\mathrm{X}$ \\
\hline TRICHOPTERA & & & & \\
\hline Limnephilus coenosus & & $\mathrm{X}$ & $\mathrm{X}$ & $\mathrm{X}$ \\
\hline Acrophylax zerberus & & $\mathrm{X}$ & & \\
\hline DIPTERA & & & & \\
\hline Limoni id a e & & & & \\
\hline Pedicia sp. & & $\mathrm{X}$ & & \\
\hline Antocha sp. & & $\mathrm{X}$ & & \\
\hline
\end{tabular}


Table 4 (continued). Taxa found in the studied lakes.

Tableau 4 (suite). Taxons récoltés dans les lacs étudiés.

\begin{tabular}{|c|c|c|c|c|}
\hline Macropelopia sp. & $\mathbf{X}$ & $\mathrm{X}$ & $\mathrm{X}$ & $\mathrm{X}$ \\
\hline Apsectrotanypus trifascipennis (Zetterstedt) & $\mathrm{X}$ & & & \\
\hline Procladius sp. & & $\mathrm{X}$ & $\mathrm{X}$ & \\
\hline Zavrelimyia sp. & $\mathrm{X}$ & & $\mathrm{X}$ & $\mathrm{X}$ \\
\hline Tanypodinae (juv.) & & $\mathrm{X}$ & $\mathrm{X}$ & $\mathrm{X}$ \\
\hline Heterotrissocladius marcidus (Walker) & $\mathrm{X}$ & $\mathrm{X}$ & $\mathrm{X}$ & $\mathrm{X}$ \\
\hline Cricotopus (C.) gr. fuscus & & & $\mathrm{X}$ & $\mathrm{X}$ \\
\hline Cricotopus (Isocladius) sp. & $\mathrm{X}$ & & & \\
\hline Psectrocladius (P.) gr. sordidellus & & & $\mathrm{X}$ & $\mathrm{X}$ \\
\hline Psectrocladius (P.) sp. & $\mathrm{X}$ & & & \\
\hline Chaetocladius gr. vitellinus & & $\mathrm{X}$ & & $\mathrm{X}$ \\
\hline Limnophyes sp. & & $\mathrm{X}$ & & \\
\hline Smittia sp. & & $\mathrm{X}$ & & \\
\hline Corynoneura sp. & $\mathbf{X}$ & $\mathrm{X}$ & $\mathbf{X}$ & $\mathrm{X}$ \\
\hline Orthocladiinae (juv.) & $\mathrm{X}$ & $\mathrm{X}$ & & $\mathrm{X}$ \\
\hline Chironomus sp. & & & $\mathrm{X}$ & \\
\hline Dicrotendipes sp. & $\mathrm{X}$ & & $\mathrm{X}$ & \\
\hline Endochironomus sp. & & & $\mathrm{X}$ & \\
\hline Tanytarsus lobatifrons Kieffer & $\mathbf{X}$ & $\mathrm{X}$ & & \\
\hline Micropsectra sp. (M. radialis) & $\mathrm{X}$ & $\mathrm{X}$ & & $\mathrm{X}$ \\
\hline Paratanytarsus austriacus Kieffer & $\mathbf{X}$ & & $\mathrm{X}$ & \\
\hline Tanytarsini (juv.) & $\mathbf{x}$ & $\mathrm{X}$ & $\mathrm{X}$ & $\mathrm{X}$ \\
\hline COLEOPTERA & & & & \\
\hline Hydroporus ferrugineus Steph. & & $\mathrm{X}$ & & \\
\hline Hydroporus nivalis Heer & & $\mathrm{X}$ & & \\
\hline Hydroporus palustris (L.) & & & $\mathrm{X}$ & \\
\hline Hydroporus sp. & & & & $\mathrm{X}$ \\
\hline Agabus solieri (Aube) & & $\mathrm{X}$ & $\mathrm{X}$ & $\mathrm{X}$ \\
\hline Agabus congener (Thunb.) & & & & $\mathrm{X}$ \\
\hline Agabus sp. & & $\mathrm{X}$ & $\mathrm{X}$ & \\
\hline Hydraenidae (larvae) & & $\mathrm{X}$ & & \\
\hline Dytiscidae (larvae) non det. & $\mathrm{X}$ & & & \\
\hline HYDRACARINA (juv.) non det. & $\mathrm{X}$ & $\mathrm{X}$ & & \\
\hline
\end{tabular}

taxa like Cognettia, Diptera Limoniidae or Smittia sp. was present. On the shore of this lake there are patches of early stage vegetation (mainly mosses) where amphibious species can find shelter no matter the water level. The presence of amphibious taxa in high mountain water bodies is known also from other mountain regions like Alpen (Reiss 1968). Shores of Dwoisty Staw lakes are devoid of vegetation and despite periodic changes of water level, the above mentioned taxa are absent or only represented by very few species and specimens. It substantiates the importance of such a vegetation as the main habitat for amphibious species.

In Dwoisty Staw lakes, complete water disappearance and bottom freezing may limit the number of species characteristic for these lakes because wintering individuals belonging to some taxa (e.g. Naididae) and their cocoons are sensitive to freezing for longer of time. For other species, such as Branchinecta paludosa, a glacial relict, eggs freezing is necessary for the life cycle. However, that species disappeared from both Dwoiste Staw lakes. Dyduch-Falniowska (1992) explains it by an increased acidification, but such an explanation seems very unconvincing. This species lives on far North, in acidified, periodical lakes and also in Wyzny Furkotny lake (Slovak Tatra Mts.), where the amount of acid rains is similar to that in the Polish part of Tatra. The extinction of Branchinecta paludosa in Dwoisty Staw lakes might have been caused by other factors like uncontrolled introduction of fish or outbreak of parasites. In the case of small, isolated populations such causes may lead to the extinction of species. 
The character of the benthic fauna of Zielony Staw lake, especially in its deep part, is entirely different when compared with the remaining lakes. It seems that the higher trophy is the most important factor determining the composition of the benthic community. While, in already discussed lakes, Enchytraeidae dominated among oligochetes, only in Zielony Staw lake Tubificidae and Naididae dominated as it was found in Pyrenean lakes (Juget \& Giani 1974). Also, Pisidium find there adequate food conditions. It is hard to determine the influence of fish predation on benthos inhabiting the profundal area of mountain lakes (Giani \& Lucas 1974). Nevertheless, the results of fish feeding could be seen on the lake shore. This manifests by elimination of larger forms like Trichoptera and Coleoptera larvae. From available publications (Galewski 1971, Burakowski et al. 1976) it can be inferred that in Tatra Mts. there are 60 Coleoptera species from the family Dytiscidae (Mielewczyk 1996). Only $10 \%$ out of that number was found in the studied lakes (alt. 1657$1784 \mathrm{~m}$ ). It results from a selective elimination of species not adapted to oligotrophic conditions and severe climate. Lower diversity and numbers of Coleoptera found in Zielony Staw lake, although located at the lowest altitude, demonstrate the effect of fish feeding on Coleoptera elimination. Among Plecoptera living in Zielony Staw lake littoral only youngest larval forms were found, older ones could have been eliminated by fish.

Biocenoses living in the studied lakes tolerate well periodical changes of $\mathrm{pH}$ values but $52 \%$ of precipitation is of low pH (4.0-4.5) (Rzychon 1998) which may adversely influence the benthic fauna, which was noted first in littoral zone (Vranovský et al. 1994). It is impossible to state the decline in biodiversity which might testify to the acidification effect, since previous studies carried out on lakes situated on Gasienicowa Valley were fragmentary and revealed far less number of taxa than that found in our study. The influence of acid rains on changes in the composition of bottom fauna should be continuously monitored, especially in lakes with very low buffering capacity and trophy where the mechanism of self-regulations of lake ecosystems may fail fast. Not all lakes situated on granite are equally susceptible to acidification, e.g. in the Pyrenees mountains despite low levels of $\mathrm{Ca}$ and $\mathrm{Mg}$, water pH was alkaline (Capblancq \& Laville 1968). The attempts of explanation of acidification effect on high mountain lakes, based only on water chemistry changes, are unsatisfactory. The data from fauna communities should also be taken into account as it was made in studies on Scandinavian lakes (Fjellheim \& Raddum 1990).

\section{Acknowledgement}

The authors wish to express their gratitude to Prof. B. Szczesny for determination of Trichoptera.

This work was supported by Commission of the European Communities ( $\mathrm{N}^{\circ}$ EV5V-CT92-0205 and $\mathrm{N}^{\circ}$ ENV4-CT95-0007) and by the Polish State Committee for Scientific Research $\left(\mathrm{N}^{\circ} 6\right.$ PO4F 017 13).

\section{References}

Bombówna M. \& Wojtan K. 1996. - Zmiany sktadu chemicznego wody jezior tatrzanskich na przestrzeni lat. In : Z. Krzan (Ed.). Tatra National Park, Nature and Man, Vol.III, Kraków, Zakopane, 56-59.

Burakowski B., Mroczkowski M. \& Stefanska J. 1976. - Chrzaszcze, Coleoptera, Adephaga prócz Carabidae, Myxophaga, Polyphaga: Hydrophiloidae. Katalog fauny Polski. PWN, Warszawa, vol. $23: 307 \mathrm{p}$.

Capblancq J. \& Laville H. 1968. — Etude morphométrique et physico-chimique de neuf lacs du massif de Néouvielle (Hautes-Pyrénées). Annls Limnol., 4 (3) :275-324.

Dyduch-Falniowska A. 1992. - Branchinecta paludosa (O.F Müller, 1788) Skrzeloptywka bagienna. In : Z. Gtowacinski (Ed.) Polish red data book of animals. PWRL, Warszawa : 257-259.

Dyduch-Falniowska A. \& Smagowicz K. 1980. - Branchinecta paludosa in the Polish Tatra Mts. Chronmy Przyrodê Ojczysta, 36 : 45-49.

Fjellheim A. \& Raddum G.R. 1990. - Acid precipitation : Biological monitoring of streams and lakes. Sci. Tot. Environm., 96 : $57: 66$.

Frost D., Huni A. \& Kershaw E.E. 1971. — Evaluation of a kicking technique for sampling stream bottom fauna. Can. J. Zool., 49 : 167-173.

Galas J., Dumnicka E., Kawecka B., Kownacki A., Jelonek M., Stós P. \& Wojtan K. - 1996. Ekosystemy wybranych jezior tatrzanskich - polski udziat w miédzynarodowym programie AL : PE2. In : A. Kownacki (Ed.). Tatra National Park, Nature and Man, vol. Il Biology. Kraków- Zakopane : 96-99.

Galewski K. 1971. - Ptywakowate (Coleoptera, Dytiscidae) Bieszczadów. Fragm. Faun., 17 : 179-211.

Giani N. \& Lucas C. 1974. - Les sédiments d'un lac haute montagne : structure, nature et peuplement. Annls Limnol., 10 (3) : 223-244.

Gliwicz M. 1985. - Predation or food limitation : an ultimate reason for extinction of planktonic cladoceran species. Arch. Hydrobiol. Beih., Ergebn. Limnol., 21 : 419-430.

Hrabe S. 1942. - O bentické zvirene jezer ve Vysokých Tatrách. Physiographica Slovaca, 1 : 124-177.

Juget J. \& Giani N. 1974: - Répartition des Oligochètes lacustres du Massif de Néouvielle (Hautes-Pyrénées) avec la description de Peloscolex pyrenaicus n.sp. Annls Limnol., 10 (1) :33-35.

Kopácek J. \& Stuchlík E. 1994. - Chemical characteristics of lakes in the High. Tatra Mountains, Slovakia. Hydrobiologia, $274: 49-56$.

Kowalewski M. 1917. - Marionina tatrensis M. Kowalewski nowy przedstawiciel rodziny Enchytraeidae. Rozp. Wydz. Matem.-Przyr. AU Ser III T. $16: 1-8$.

Kownacki A. 1985. - Effect of droughts on the invertebrate communities of high mountain streams. Verh. Internat. Verein. Limnol., 22 : 2069-2072.

Laville H. 1971 a. - Recherches sur les Chironomides (Diptera) lacustres du Massif de Néouvielle. Première partie : Systématique, Ecologie, Phénologie. Annls. Limnol., 7 : 173-332. 
Laville H. 1971b. - Recherches sur les Chironomides (Diptera) lacustres du Massif de Néouvielle. Deuxième partie : Communautés et production. Annls. Limnol., 7 (3) : 335-414.

Laville H. \& Giani N. 1974. - Phénologie et cycles biologiques des Chironomides de la zone littorale $(0-7 \mathrm{~m})$ du lac de Port-Bielh (Pyrénées centrales). Ent. Tidskir., Suppl. 95 : 139-155.

Litynski A. 1917. - Jeziora tatrzanskie i zamieszkujaca je fauna wioslarek. Spraw. Kom. Fizjograf., 51 : 1-88.

Mielewczyk S. 1996. - Stan poznania chrzaszczy wodnych z podrzédu Adephaga Tatrzanskiego Parku Narodowego. In : A. Kownacki (Ed.). Tatra National Park, Nature and Man, vol. II Biology. Krak6w- Zakopane : 92-93.

Minkiewicz S. 1914. - Przeglad fauny jezior tatrzanskich. Spraw. Kom. Fizyogr., 48 : 114-137.

Oleksynowa K. \& Komornicki T. 1989. - Some new data on the composition of the waters in the Tatra Mountains. Part VIII. Valley Sucha Woda. Zesz. Nauk. AR w Krakowie, 28 : 3-31.

Olszewski P. 1948. - Zimowe stosunki tlenowe wiekszych jezior tatrzanskich. Rozprawy Wydz. Mat.-Przyr., 72: 186-264.

Reiss F. 1968. - Verbreitung lakustrischer Chironomiden (Diptera) des Alpengebietes. Ann. Zool. Fenn., 5 : 119-125.
Rzychon D. 1998. - Wptyw opadów kwasnych na zakwaszanie jezior Tatr Wysokich. Prace naukowe Uniw. Slaskiego, Katowice $1998: 132 \mathrm{p}$

Rzychon D. \& Worsztynowicz A. 1995. - The role of nitrogen in acidification of Tatra Mountains lakes. Water, Air and Soil Pollution, $85: 481-486$

Standard Methods For the Examination of Water and Wastewater. 1992, 18th Edition, Washington.

Thienemann A. 1954. - Chironomus. Leben, Verbreitung und wirtscaftliche Bedeutung der Chironomidae. In : Die Binnengewässer, Band XX, Stuttgart : 834 p.

Vranovský M., Krno I., Sporka F. \& Tomajka J. 1994. — The effect of antrophogenic acidification of the hydrofauna of the lakes of the West Tatra Mountains (Slovakia). Hydrobiologia; 274 : 163-170.

Wojtan K. \& Galas J. 1994. - Acidification of small mountain lakes in the High Tatra Mountains, Poland. Hydrobiologia, 274 : 179-182.

Zavrel J. 1935. - Chironomidenfauna der Hohen Tatra. Verh. Internat. Verein. theor. angew. Limnol., $7: 439-448$. 